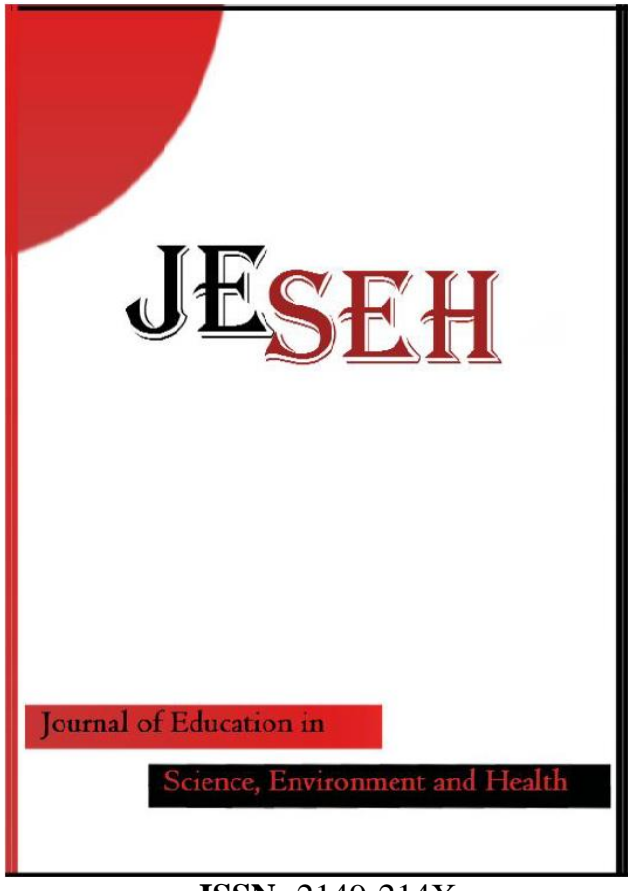

ISSN: $2149-214 \mathrm{X}$

\section{Journal of Education in Science,} Environment and Health

www.jeseh.net

How Do Theist (Muslim) Pre-Service Science Teachers Reconcile Their Individual Ontologies with Premises of Modern Science

Halil Turgut

Sinop University

To cite this article:

Turgut, H. (2019). How do theist (muslim) pre-service science teachers reconcile their individual ontologies with premises of modern science. Journal of Education in Science, Environment and Health (JESEH), 5(2), 164-177. DOI:10.21891/jeseh.568796

This article may be used for research, teaching, and private study purposes.

Any substantial or systematic reproduction, redistribution, reselling, loan, sub-licensing, systematic supply, or distribution in any form to anyone is expressly forbidden.

Authors alone are responsible for the contents of their articles. The journal owns the copyright of the articles.

The publisher shall not be liable for any loss, actions, claims, proceedings, demand, or costs or damages whatsoever or howsoever caused arising directly or indirectly in connection with or arising out of the use of the research material. 


\title{
How Do Theist (Muslim) Pre-Service Science Teachers Reconcile Their Individual Ontologies with Premises of Modern Science
}

\author{
Halil Turgut
}

\begin{tabular}{|c|c|}
\hline Article Info & Abstract \\
\hline Article History & \multirow{8}{*}{$\begin{array}{l}\text { The purpose of this study was to investigate how theist (Muslim) pre-service } \\
\text { science teachers' reconcile their individual ontologies, which stem from their } \\
\text { worldviews, with premises of modern science. } 23 \text { pre-service science teachers } \\
\text { ( } 10 \text { males and } 13 \text { females, ages ranged from } 19 \text { to } 23 \text { ) were selected by } \\
\text { purposeful sampling. Data sources included open-ended questions and semi- } \\
\text { structured follow-up interviews. The qualitative analysis of data revealed that } \\
\text { theist participants believing in a created Nature which is being lawful and } \\
\text { understandable but also open to supernatural intervention diverged in their } \\
\text { perspectives about the ontological premises that scientists must have and } \\
\text { presupposed theism, theism/naturalism or just naturalism for doing science. } \\
\text { They all asserted the physical universe as the boundary for science and } \\
\text { evaluated the possibility of the scientific investigation of miracles and jinn } \\
\text { within that boundary with the criterion of being able to obtain empirical data } \\
\text { They did not perceive any incompatibility between science and Islam and } \\
\text { proposed methodological naturalism for scientific practice in order to overcome } \\
\text { potential conflicts. }\end{array}$} \\
\hline Received: & \\
\hline 15 February 2019 & \\
\hline $\begin{array}{l}\text { Accepted: } \\
\text { 23 June } 2019\end{array}$ & \\
\hline Keywords & \\
\hline Ontological assumptions & \\
\hline & \\
\hline $\begin{array}{l}\begin{array}{l}\text { Premises of modern } \\
\text { science }\end{array} \\
\text { lat }\end{array}$ & \\
\hline
\end{tabular}

\section{Introduction}

Developing students' understandings of the nature of science (NOS) has been valued as an important aim of science education and the common aspects of NOS for the science education community are discussed in various documents (McComas, Clough \& Almazroa 2000; Lederman, Abd-El-Khalick, Bell \& Schwartz 2002). However, current discussions of the aspects of NOS are mainly based on epistemological and methodological issues. Basic ontological issues in regard to the subject matter of science in comparison with other ways of knowing (e.g. religion) are not explicitly being discussed in the science education community. Although there are some arguments, within the scope of NOS, about empirical and objective nature of the physical world that could be used to start a discussion about the nature of entities being investigated within the realm of science; such arguments are in need to be clarified for science educators. For this, science education community must focus on worldview studies which provide a theoretical foundation for ontological presuppositions of modern science. Hence, with that ontological basis, it would be more meaningful to reflect on epistemological and methodological issues of the NOS.

\section{Worldview Studies}

Worldviews are culturally organized macro-thoughts that provide dynamically inter-related presuppositions about the world (e.g. what it is really like, how can valid knowledge be derived). Worldviews also affect the individuals' decision-making processes as well as their conceptions of science (Kearney 1984; Cobern 1994). Related literature reports similar relationships between students' worldviews and their understandings of science (Allen \& Crawley 1998), worldviews and epistemological beliefs (Tsai 2001), culture and perceptions about science (Sutherland \& Dennick 2002). According to Liu \& Lederman (2007) students may have alternative worldviews that are incompatible with science and teachers with more traditional worldviews may have inaccurate conceptions of the NOS.

A comprehensive understanding of the NOS (beyond having some declarative knowledge about it) means to understand science as a way of knowing and to be able to compare science with other ways of knowing. In this context, the issue must initially be based on ontological assumptions. However, the conflicts between worldviews (scientific, religious etc.) are mainly perceived as the differences in religious beliefs, moral values, 
socio-economic and political issues (Haack 2003). The on-going debate between evolutionists and divine creationists is a good example of such lack of recognition (Colburn \& Henriques 2006).

Metaphysical views of knowledge vary along ontological assumptions regarding the definition of Nature and form of reality (Guba \& Lincoln 1994; Uschold 1996), and epistemological beliefs dealing with the nature, sources of knowledge, and ways of knowing (Beeth \& Kwak 2001; Çakır 2011; Snively \& Williams 2008). Further, these assumptions and beliefs also vary between the knowledge systems (Aikenhead 2006; Dilworth 2006), the natural sciences (physics, chemistry, biology) and even the science topics within domains (classical/quantum mechanics, classical biology/ecology) (Dilworth 2006; Yore 2008). Therefore, the metaphysical core of modern science must be explicitly examined in order to understand science as a way of knowing and its boundaries.

\section{Metaphysical Presuppositions}

There is a variation of metaphysical views between indigenous, religious and scientific knowledge systems. The metaphysical assumptions are viewed as demarcating units to be examined in order to espouse the unique ontological and epistemological features of science as contrasted to others (Yore 2008). Modern science is assumed to be guided by the assumptions about the Universe; such as being knowable through rational/empirical means and eradicating mystery/spiritualism in favor of physical causality (Aikenhead 2006). It involves the notion of the cause-effect and mechanistic explanations which are mostly contrary to the basic assumptions of the indigenous ways of knowing. Matthews (2009a) stated that scientific inquiry of Nature presupposes certain metaphysical assumptions such as the existence of an external world which is independent of the observer, the universality of causation in that world, and the constancy (time-space) of causation. He also added an epistemological commitment, which is the opportunity of coming to know the external world, and an epistemic presupposition, which is the central role of evidence in deciding upon truth or falsity of a claim. Similarly, Cobern and Loving (2001) discussed the critical attribute of science as being naturalistic and labeled science as a material exploratory system which is objectively and empirically testable. Haack (2003) demarcated science from religion by stating that religion is a body of beliefs whereas science is a kind of inquiry. According to him, the core of religious worldview is the idea of a purposeful spiritual being that brought the universe into existence with a special place given to human beings and is concerned about how human beings behave and believe. This spiritual being is thought to be influenced by prayers and rituals. In addition, contrary to science, religions are asserted to be focused on absolute truths with supernatural explanations which are based on the authority of sacred text and faith (Yore \& Knopp 2001).

Dilworth (2006) focused on basic ontological principles or presuppositions of modern science instead of epistemological and methodological ones. The rationale for his position was the relation of methodological and epistemological presuppositions with the ontological ones. For instance, the experimental method was supposed to give epistemologically valuable and replicable results because scientists assumed that Nature was ontologically uniform in a particular sense. The adoption of the experimental method itself was assumed to involve ontological presuppositions and it was asserted that in order to commit to a particular methodology, one must have a particular conception about the nature of the subject matter that is investigated. So, basic presuppositions (or principles) of modern science were taken to be ontological which were stated as general assumptions regarding the nature of the entities that modern science set itself to examine. Dilworth (2006) emphasized that presuppositions constituted the core (rather than the foundation) of the modern science and delineated an ontological paradigm or an ideal conception of the reality for scientists. The core presuppositions of the modern science highlighted by him were; (i) uniformity of Nature, (ii) principle of substance and (iii) principle of causality. The principle of the uniformity of Nature concerns a lawful natural change. This principle implies determinism but this determinism is not strictly required (e.g. probabilistic laws). The particular form of uniformity presupposition is that similar states of Nature are followed by similar states and location in homogenous space and time are not constituents of any state. The second presupposition, the principle of substance (or principle of the perpetuity of substance), is also related to the conception of change. It formulates change as alteration of the substance (material) which exists perpetually. In this context, it is assumed that no portion of substance either comes into or goes out of existence. The last presupposition, the principle of causality states that change is caused and restricts causes to natural entities, hence excludes supernatural causes from modern science. 


\section{Aim and Rationale of the Research}

The literature on the NOS is mainly focused on various epistemological and methodological issues that are related to modern science. But, ontological assumptions in regard to the subject matter of science are not mentioned or discussed explicitly. The discussion of metaphysical assumptions or presuppositions (especially ontological ones) of different ways of knowing should not be left to small interest groups. This issue must be scrutinized within the science education community in a meaningful way in order to develop a qualified understanding of the NOS with a philosophical basis. The students in science courses should be informed about the presuppositions of various ways of knowing and hence be directed to question how reason operates in different disciplines (Cobern 2000a). Similarly, science educators should understand the consequences of such philosophical questions and their adopted answers about knowledge prevalent in the curriculum (Snively \& Williams 2008). The first attempt in this approach should be to identify the current conceptions and basic assumptions of educators of science (and candidates) about the metaphysical core of the modern science as part of their worldviews.

The main purpose of this research was to investigate theist pre-service science teachers' perspectives of the compatibility of their worldviews with presuppositions of the modern science. In order to achieve this goal, the framework of steadily growing research on exploring the relationship between science and supernatural was adopted as the context of the study and the participants'; (i) individual impressions about Nature, (ii) ontological assumptions they assert for doing science, (iii) conceptions about the relationship between science and supernatural beings, and (iv) perceptions regarding the position of Islam originated knowledge claims in modern science were examined.

\section{Method}

The qualitative research approach (Creswell 2012) was adopted in order to reveal and interpret Turkish theist pre-service science teachers' perceptions of science and supernatural through their ontological assumptions about Nature. The participants of the study, the data sources, and the process of analysis are presented below.

\section{Participants}

The participants of the study were determined by purposeful sampling strategy within data collection process (Creswell 2012). The first criterion for selection was that the participants had not had any formal instruction about Philosophy and Nature of Science. The purpose of this criterion was to sample the participants who constructed their opinions about the relationship between science and supernatural within the context of their own cultural ecologies. The second selection criterion was that participants were theist, that is had belief in a personal God who is the creator of the universe and interacts with the universe as in the prayerful activities of humans (Smart \& Haldane 1996), and were willing to explicitly express their individual worldviews in confidence. In order to implement these criteria for participant selection, the researcher developed open-ended questions that were administered to the class of 33 third grade pre-service science teachers at the first week of The Nature of Science and The History of Science course as a pre-instruction activity. Any material related to the content of open-ended questions was not presented to candidates until the data collection process ended. The compulsory course taught by the researcher for three hours a week was chosen to provide participants an authentic atmosphere in the scope of the research. All students enrolled in the course responded to the openended questions in written format individually and after initial analysis of the answers for their explicitness and persistence, 23 theist candidates (10 males and 13 females with ages ranged from 19 to 23) were identified as participants of the study. Participants who were not theists (4 deists, 2 atheists) and not willing to participate (4 theists) were excluded from the study.

\section{Data Sources}

Open-ended questions and semi-structured follow-up interviews were used to collect data (in a two-tier process). During the first step, the open-ended questions were used to collect preliminary information about participants' conceptions of Nature, science and supernatural. Then the semi-structured follow-up interviews which were based on the participants' responses of open-ended questions were conducted. The data collection process was performed as pre-instruction activities in the context of The Nature of Science and The History of Science course. 
Participants' conceptions of presuppositions of the modern science in relation to supernatural were assessed primarily focusing on their ontological assumptions about Nature. The open-ended questions (see Appendix) used for that aim were designed in order to provide respondents with an opportunity to express their perspectives freely by widening any discussion in any context they deemed appropriate. They were developed and validated by the researcher in a previous study (Turgut 2011) about worldview issues such as beliefs about Nature, apriori assumptions in science, religious beliefs and science, comparability of science and religion, and adopted for this research.

The first open-ended question was aimed to elicit the participants' impressions about Nature (e.g. if Nature is eternal, lawful and open to supernatural intervention). Since the concept of Nature is quite profound and not easily addressed extemporaneously (Cobern 2000b), it was not simply asked as 'What is Nature?' Three mainstream approaches, namely theism, deism and materialism, were briefly summarized before asking participants to write and discuss their perceptions about Nature. Therefore, in the first question participants wrote down and clarified their individual perspectives in relation to those mainstream views, or any others they perceived that reflects their opinions. The second open-ended question focused on their perceptions of the presuppositions of scientists while doing science. The participants were asked to compare their individual assumptions of Nature with the ones that were presupposed by the scientists. The remaining four questions were about the relationship between science and supernatural (such as the Allah, miracles, and jinn), science and Islam originated knowledge claims, and science and faith. Therefore, the overall purpose of the open-ended questionnaire was to elicit and clarify participants' perspectives of science in relation to supernatural (Islam) on the basis of their individual ontologies. The intention of each open ended-question is summarized below in table1.

Table 1. Open-ended questions and their intends

\begin{tabular}{ll}
\hline Question & Intend \\
\hline Q1 & Perceptions about Nature \\
Q2 & Perspectives regarding presuppositions of scientists about Nature while doing science \\
Q3 & Perceptions about relationship between science and supernatural \\
Q4 & Perceptions about boundaries of science and examination of supernatural (miracles, jinn) \\
Q5 & Perceptions about scientific investigation of religious propositions regarding physical entities. \\
Q6 & Perceptions about the role of faith in scientific practice. \\
\hline
\end{tabular}

Although each open-ended question aimed to elucidate a certain aspect of the participants' perspectives, they were transitive in that they directed participants to ponder about science, supernatural and their relation in various contexts as a whole. The open-ended questions were designed to stimulate participants' reflections and thinking about the concepts they used. Their answers to different questions allowed the researcher to evaluate the consistency of individual answers. Participants answered the questions in written format in approximately 40-50 minutes. They were asked to support all their answers by providing an explicit rationale. In order to encourage participants to share their actual opinions, rather than what they believe is acceptable, they were asked to use nicknames or symbols in their answer sheets instead of their real names.

\section{Follow-Up Interviews}

Initially, participants' responses to the open-ended questions were analyzed by the researcher. During document analysis, the participants' responses were carefully coded and follow up questions were developed for the interviews. Hence, the contents of the semi-structured follow-up interviews were individually crafted for each participant. Such an approach enabled the researcher to perform in-depth analysis of each participant's conceptual framework. Moreover, participants' points of view were probed and investigated for the meaning and understanding attached to their individual experiences (Kvale \& Brinkmann 2009). Once the semistructured interview protocols were ready, the schedule for the interviews was announced in class, with reference to nicknames. Participants who felt uncomfortable to verbally participate in an interview were allowed to respond the interview questions in written format. This was a crucial and necessary measure because of cultural and social pressures that some of the participants may have felt. They may have felt uncomfortable to share their worldviews with the instructor worrying about being labeled as religious or vice versa. The majority of the participants ( 8 females and 7 males) gave their consent for face to face follow-up interviews that were conducted on campus in the office of the researcher. 
The follow-up interviews started with providing participants with their own answer sheets to open-ended questions. Then the researcher's notes and follow-up probing questions were provided to them for further clarification and elaboration of the responses. The interview process was flexibly designed allowing the researcher to ask prepared questions that covered the related topics, as well as to explore the issues emerging during the interview (King \& Horrocks 2010). For instance, a participant who responded to the open-ended question as 'Jinn can be subject of science... Jinn is a nonphysical being and cannot be examined...' was asked to explain how he/she thought that a nonphysical being could be subject of science. Similar conversations were carried out in order to understand the participant's conception without any sign of judgment or sense of inconsistency. Each interview lasted approximately 20-30 minutes.

A similar procedure was followed for the participants who did not prefer to participate in face to face interviews. The answers these participants provided to the open-ended questions were reviewed and re-circulated to them in class using their nicknames. For each of their answers that were found to be confusing or open to misinterpretation, the researcher posed new questions or requested explanations in comment boxes, and participants were asked to respond to them in an additional answer sheet. The participants completed this task in 20-30 minutes and returned their responses to the researcher.

\section{Data Analysis}

In the first step of the data analysis, a data set was formed for each participant (including the answer sheet of open-ended questions and interview document/additional answer sheet) and was labeled (e.g. PST1; PST1 stands for Pre-Service Science Teacher One). Then, an initial superficial examination of the data was performed for each participant's data set to see if any possible misinterpretation or inconsistency still existed either for respondent or researcher. At the end of this stage, it was concluded that data collection process could end. Afterwards, actual data analysis was conducted comparatively within each participant's data set.

During the analysis process, interview documents or additional answer sheets were integrated with responses to open-ended questions to facilitate the examination of data set. The responses from those documents were compiled with the related responses to open-ended questions. Each participant's data set was treated as an uninterrupted text and their responses were viewed holistically since the open-ended questions were transitive. It was observed that participants sometimes responded to a question by referring to another one and performed a multifaceted approach.

After the organization of data for actual analysis, the data set for each participant was considered separately before searching patterns across the whole group since the research had an idiographic nature and comprised complex individual thinking (Taber, Billingsley, Riga \& Newdick 2011). In this process, each participant's written responses and interview documents were read comparatively and any bit of information stated by a word, sentence or whole paragraph was labeled and coded to establish the initial list of codes. With the help of those codes, the participants' individual positions were further clarified and evaluated in order to resolve any purported contradiction that was not considered earlier. For instance, a participant had expressed that he/she is against restricting science and then indicated that jinn cannot be investigated scientifically since any empirical evidence could not be obtained. That participant's list of codes was re-examined as a whole (including the ones related with miracles, Supreme Being etc.) and then it was considered that in fact he/she restricted the subject matter of science to physical entities.

In the second phase of the analysis, the initial codes which were developed for each participant were reviewed and through constant comparative method similar and related codes were combined to form more general categories (Gay, Mills \& Airasian 2006; Bogden \& Biklen 2007). The same process was repeated for the whole study group in order to develop the final list of codes. A brief sample of final codes developed for participants' positions with regard to the presuppositions of scientists' about Nature is presented in table 2.

Table 2. Sample position and related codes

\begin{tabular}{ll}
\hline Position & Codes \\
\hline Scientists presuppose Theism & Faith in Allah as the major cause \\
& Faith in Allah as the motivator \\
& Faith in Allah as the source of order \\
\hline
\end{tabular}

In third and final phase of the analysis, the final codes were scrutinized for their power of representation by reviewing the participants' data sets which also enabled the researcher to determine the frequencies of those 
codes across data. When it was decided that the final codes represented the data adequately, participants were categorized according to their positions and the analysis process was ended.

\section{Results}

The main proposition of theist participants of this study was that Nature operates lawfully as a system with the laws/principles set by Allah. However, they also believed that Nature is open to supernatural intervention. They accepted some exceptional cases, also called miracles, within lawful Nature. Miracles are events reported in divine texts and in history of the religion, in this case Islam, in which the laws of Nature are distorted. Theist participants were mostly impressed by and admired the laws of Nature and the beauty of the creation of Nature. According to them science is an endeavor for discovering the laws of Nature in order to understand how Allah acts. However, participants proposed three different orientations when they were asked about the presuppositions of scientists about Nature while doing science. These orientations were (i) theism, (ii) theism and/or naturalism and (iii) naturalism. The branching proceeded in relation to the issues of science, supernatural and the relation between them.

\section{Group 1: Theist Participants That Assumed Scientists Presuppose Theism}

A group of theist participants (10 out of 23) assumed that scientists presuppose theist conception of Nature in their scientific research. They adopted such a perspective in line with their individual ontologies and although had indicated that science is restricted to physical universe (Nature), they all tried to make room for Allah in the scientific discourse as the creator and source of the order in the universe. Their stances comprising presuppositions of modern science and supernatural entities are outlined in figure 1.

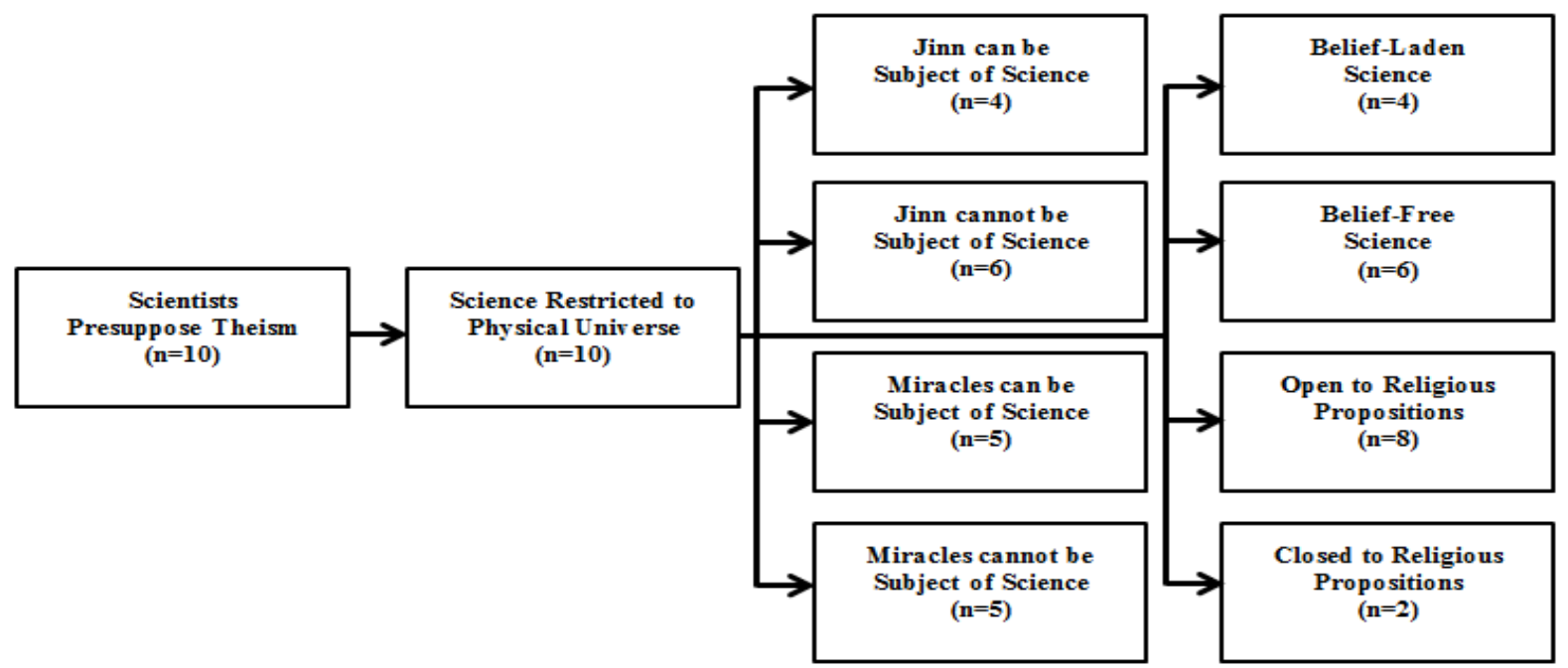

Figure 1. Stances of theist participants who assumed theism in science

While asserting a theist assumption of Nature by scientists, the basic notion of these participants was that the scientists' motivation for inquiring into order in the universe was to appreciate the art of Allah. Within this perspective Allah is the major cause of everything in the universe and faith in Allah was presented as the meaning of life.

Scientists search for the laws and this means order. So doing science requires accepting that there is a knowable order in Nature. We know that a system with an order cannot survive without a regulator. I believe that Allah created the universe, set the rules and let the system work by itself. Believing in Allah empowers the scientist, provides him with the real meaning of life and motivates him to conduct research for understanding Nature that is created by Allah. Science does not require rejecting Allah (PST 6).

When they were asked about how to cite Allah in scientific research which is restricted to the physical universe, the participants indicated that the Supreme Being is a meta-concept for scientists and cannot be included in any equation. Rather, they claimed that scientists can accept the existence of Allah and aim to determine the physical 
principles of the universe set by Allah. Hence, they asserted that scientists can try to understand the creation while being restricted to work in the physical universe.

Allah cannot be cited in any physical equation of course or we cannot explain a phenomenon by only Allah's wish if we are doing science. Science is only about physical beings. But the point is that I can be a scientist believing in Allah who created a lawful universe and try to understand this creation by conducting science. In this case, scientific research will mean devotion (PST 10).

According to this group of participants, the idea of Allah cannot be asserted as an explicit explanation in any scientific discourse but provided a motivating factor for scientists in their research as the implicit major cause of everything. They believed that with such an assumption scientists perform an act of devotion while performing science. Those participants attempted to clarify the issue by stating the acceptance of Allah as a matter of belief operating in the background of scientists' thought system. So, they tried to overcome the purported contradiction that scientists can presuppose theism while operating just in the physical universe.

The majority of those theist participants ( 8 out of 10 ) indicated that religious texts and especially Holy Qur'an can be considered as a source of knowledge in regard to some aspects of Nature. They claimed that scientists should be open to Islamic propositions about the physical universe and perform research based on those propositions.

In the case of being open to empirical investigation, testing, and argumentation, scientists should examine propositions written in religious texts. But this is not possible for supernatural issues. We know that Holy Qur'an includes knowledge about the physical universe and its laws such as expansion of the universe, the origin of iron on Earth. There are many other examples (PST 14).

The participants asserted that the Holy Qur'an provides knowledge about the laws and structure of the universe and they presented examples as the ones presented above. Although none of those participants could exemplify the issue by directly citing verses from the Holy Qur'an, it was tangible that this assertion was so accurate for them. The criterion they set for the issue was being a physical phenomenon which was seen to be consistent with their assumption that science is restricted to the physical universe.

The issues of miracles and supernatural entities (such as jinn) were also questioned in regards their potential as subject matter for science, in conjunction with being open to religious knowledge claims in science. For some participants this was possible and plausible; however for some others it was not possible or plausible. When they were asked to justify their positions about the scientific inquiry of miracles and jinn, they set the condition of having direct or indirect tracks/signs in the physical universe which can be investigated.

Miracles can be subject of research that scientists investigate. As written in Holy Qur'an, they are real and occurred in the physical universe. Some of them can be explained if relevant data is obtained. If a miracle cannot be explained by the physical rules and scientific knowledge available at a time, scientists must be fair and say "it was a miracle". But jinn cannot be investigated. They are supernatural entities (PST 21).

I believe that miracles occurred historically. But they are "miracles" and hence are out of the usual order and physical laws. They cannot be examined scientifically. Why do we need to explain them scientifically? It is same for jinn (PST 10).

Not miracles but jinn can be investigated as a form of energy or field. I do not know how but in the future, as tools and methods of science will be developed, the subjects that seem to be out of science will be investigated by scientists (PST 8).

As seen in the quotations presented above, the responses of the participants were not so homogeneous for topics of miracles and jinn. Some of them accepted the possibility of the scientific investigation of both miracles and jinn; some of them rejected both. Some of them accepted miracles but rejected that jinn could be investigated scientifically and vice versa. They were consistent in their claim that science is restricted to the physical universe and any process or being must yield empirical data to be investigated scientifically.

Based upon the arguments that Allah can be cited in science as the major cause of everything in the universe and scientists can examine the Islamic knowledge claims about Nature, theist participants were also asked to argue the role of beliefs in science. The question related to whether the research of atheist and theist scientists could be 
reconciled. The group was divided into two on this issue. Six of them indicated that since their subject matter is the physical universe they will reach the same results whereas four of them asserted that their conclusions will be different.

There would not be any differences. Scientists work on objective, empirical entities and they would not wear religious clothes while conducting science. Theist believes in Allah, atheist rejects Creator but then theist will not cite Allah in any explanation. They will reach the same physical laws. The only difference would be the interpretation of major cause (PST 11).

An atheist rejects the existence of Supreme Being and this affects his/her perspective and interpretation of the research. The same is also true for a theist. Two scientists with different belief systems will work in the light of their assumptions and hence should arrive at different conclusions (PST 3).

The participants who purported that atheist and theist scientists will reconcile used the motive of objective and empirical nature of entities being investigated while conducting research. Their claim was seen to be restricted to the visible side of scientists' conclusions such as formulated physical principles and laws. Indeed, they implicitly claimed that atheist and theist scientists will differ in the meaning they attributed to the universe; if it operates by itself or if the Supreme Being intervenes in it. On the other hand, the notion of belief-laden science and hence possible differences in atheist and theist scientists' research were explicit in the rest of the group.

\section{Group 2: Theist Participants That Assumed Scientists Presuppose Naturalism/Theism}

A group of theist participants (10 out of 23) assumed that scientists could presuppose either theist or naturalist conceptions of Nature while conducting scientific research. These participants did not consider any functional differences between those two radically discrete worldviews (theism/naturalism) but some of them gave priority to theism in performing science. Their claims for the issues raised in this research are not mentioned in detail here since they were so similar to those in Group 1. This section is focused on the rationale of theist participants who were open to naturalism in science. Their stances comprising presuppositions of modern science and supernatural entities are outlined in figure 2.

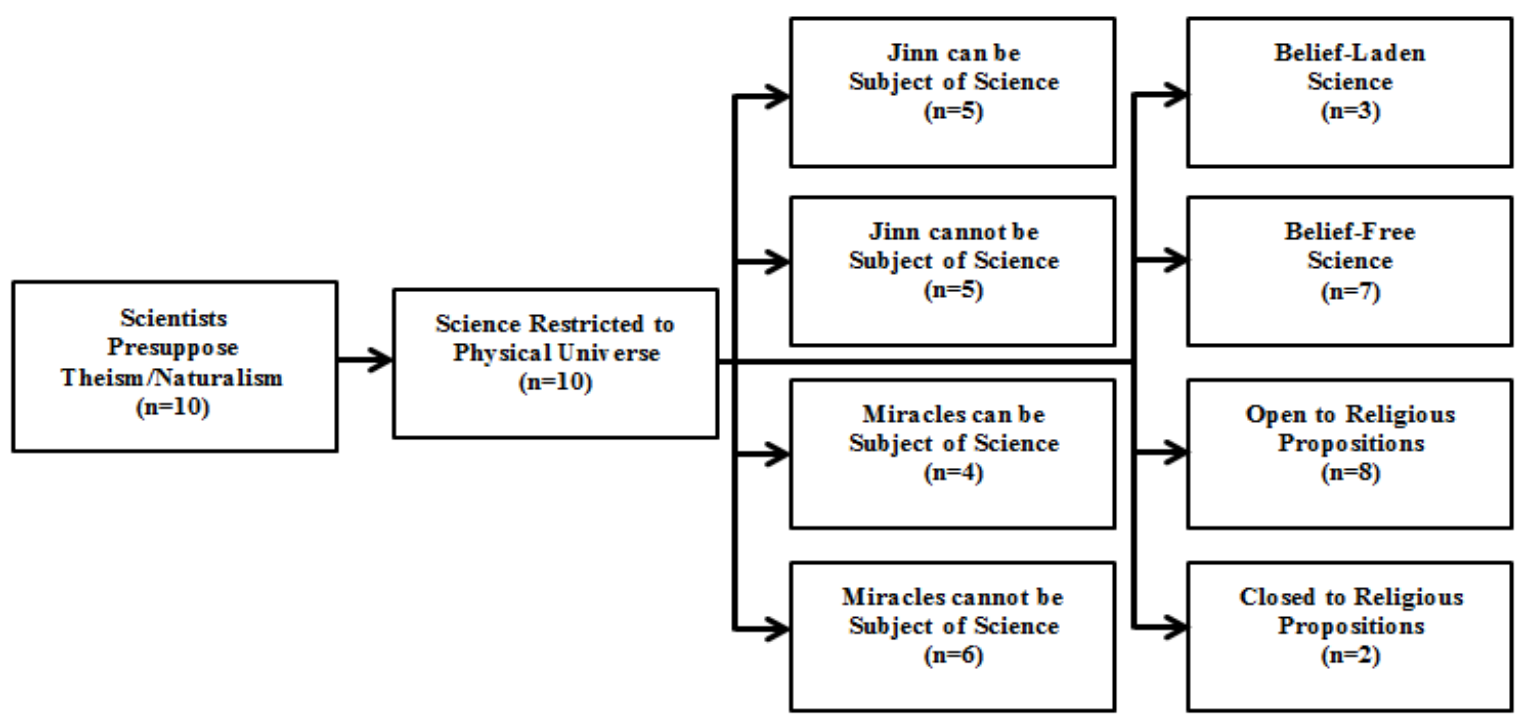

Figure 2. Stances of theist participants assuming naturalism/theism in science

Theist participants of this group believed in a created Nature which operates according to the laws set by Allah. In addition, they asserted that Nature is open to supernatural intervention. As was the case for Group 1, all stated that the practice of science is restricted to physical universe (Nature). The majority of them accepted the inclusion of the idea of Allah as a meta-concept in the scientific discourse as the creator and source of the order governed in the universe. In contrast to the first group of theists, these participants were also open to a naturalist conception of Nature to some degree in doing science.

Scientists can operate under both naturalist and theist prepositions. They all say that Nature is lawful, working under principles set by Allah. Science is regarded as the laws, order, and principles. The only 
difference may be the acceptance of Allah. This is out of science; belief. So either naturalist or theist they will arrive to the same conclusions (PST 7).

Both can be. But in fact, theist scientists will provide more meaningful conclusions with real explanations. Naturalists will have some disadvantages and restricted with the concept of "chance" while theists will load meaning to Nature and know that Allah is the major cause. Anyway, they will find same physical laws (PST 13).

Participants in this group were divided into two categories according to their assertions. Half of them gave priority to a theist conception of Nature while the other half did not see any apparent functional difference between naturalism and theism for scientists in doing science. The common rationale for both categories was the order and lawful operation of Nature. Hence participants claimed that scientists have to reconcile their physical explanation of Nature and its principles with their metaphysical presuppositions about Nature.

Participants who assumed that scientists can have both naturalist and theist presuppositions of Nature stated similar arguments for the issues as other theists in this study such as the individual conception of Allah as the major cause, the position of religious texts and Holy Qur'an as a source of propositions about Nature, the scientific investigation of miracles/jinn and the role of the beliefs in science. The majority of them (7 out of 10) indicated that the idea of Allah cannot be cited directly in scientific texts but can play a role in the personal thought system of the scientist in relation to the big questions about meaning of life.

The position of religious texts and Holy Qur'an as a source of knowledge claims about Nature was also evaluated positively by the majority ( 8 out of 10 ) with the requirement of being open to empirical investigation. They believed in the existence of miracles and jinn referencing the Holy Qur'an. Participants' opinions were divided about whether these conceptions can be investigated scientifically, with some supporting and others rejecting this notion, but all indicated the importance of collecting empirical data for such an investigation. Finally, as was the case for Group 1, the majority of participants (7 out of 10) in this group interpreted the issue of the role of beliefs in science for atheist and theist scientists, concluding that they could reconcile any differences because of the objective/empirical nature of the entities being investigated.

\section{Group 3: Theist Participants That Assumed Scientists Presuppose Naturalism}

A small portion of theist participants ( 3 out of 23) indicated that scientists must embrace naturalist prepositions in order to conduct scientific research. They asserted that science as a way of knowing has its own worldview and scientists must adopt it in order to operate in the milieu of science. Their stances about presuppositions of modern science and supernatural entities are outlined in figure 3.

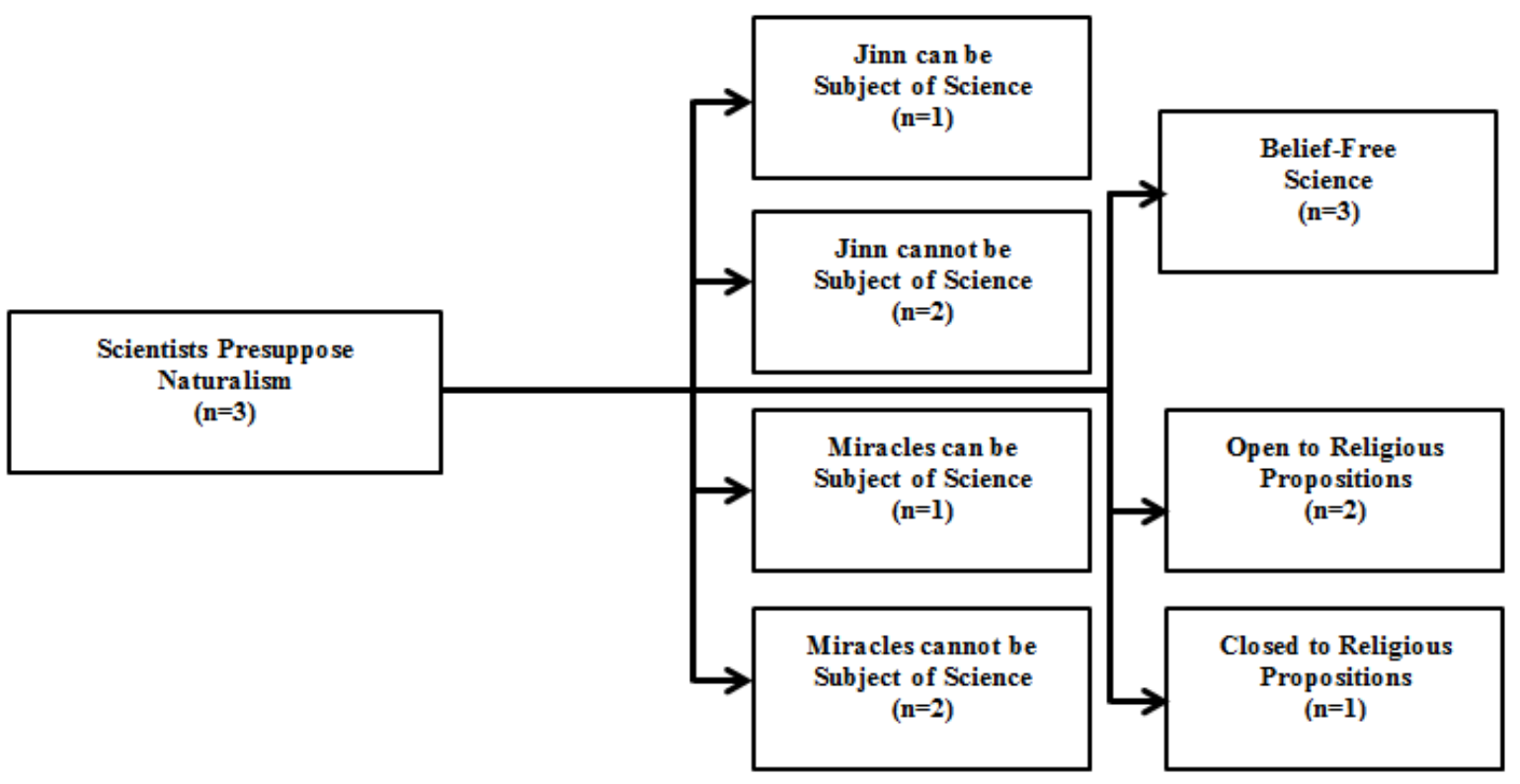

Figure 3. Stances of theist participants assuming naturalism in science 
While Group 3 participants also believed in a created and lawful Nature, they also claimed that in order to conduct scientific research one needs to put aside that faith and wear the naturalist lab coat. They stated that scientists must assume a mechanical Nature working as a machine by itself, in spite of their individual worldviews which might state otherwise.

For doing science, all scientists must have consensus on their conceptions of Nature. This must be independent of their beliefs. Science presupposes a mechanic Nature I think. It is a machine that is selfworking according to pre-determined rules. I can do science in this context while I am theist (PST 2).

A scientist must presuppose a lawful Nature operating just like a machine. Any supernatural reference should not be made. In order to build a consensus with all the other scientists he/she has to work independent of individual beliefs, either atheist or theist (PST 23).

Group 3 participants restricted the subject matter of science to physical entities and excluded the concept of Supreme Being totally from science even as a meta-concept. By doing this, they tried to establish a common ground for all scientists with various worldviews, based on physical phenomena alone. In addition, they rejected any attempt to confirm the existence of the Supreme Being since it is an issue of faith for them. This understanding aligned with their position regarding whether or not a scientist can include the acts of Allah in science.

We cannot cite Allah in science. Science is only about physical beings. In fact belief in Allah does not require any reference from Nature for me. I believe in and that is all. While doing science I try to understand only the principles and laws of Nature. Supernatural is out of science and for this reason, science is for all including also who do not believe (PST 18).

According to these three participants, the idea of Allah can neither be asserted as an explicit explanation in any scientific enterprise nor be governed as an implicit meta-concept as a matter of belief operating in the background of scientists' thought. So they indicated that science is blind to any element of faith regarded with supernatural and established a common ground for scientists who are either atheist or theist.

On the other hand, the participants differed in their views when they considered the issue relating to religious propositions, miracles, and jinn.. For instance, two of the participants purported that the verses of Holy Qur'an should be considered as a source of knowledge claims in science with regard to natural phenomena. They asserted that all propositions would be examined for empirical verification in the context of science if possible and the source would not be evaluated with bias.

Some propositions from religious texts and Holy Qur'an can be subject to science if they are open to empirical testing. The rules for science and scientific research are obvious. Any proposition from any source would be investigated if they are in the scope (PST 23).

In fact, all the participants in this group were open to empirically testable propositions from all sources. As seen in the quotation given above, their major motive was being in the scope of science as a subject matter to be investigated. While two of the participants did not reject the inclusion of propositions presented in the religious texts with regard to natural phenomena, the third participant disagreed, noting that religious texts are generally different in nature from scientific ones, and hence should be excluded.

Based upon the participants' thinking about whether religious texts could be a source of knowledge claims, the researcher questioned them further about miracles and jinn in order to understand their points of view more deeply. They were asked to justify their positions and it was identified that their major reason for accepting or rejecting miracles/jinn as the subject matter of science was being open to empirical investigation.

As we believe, miracles had occurred physically in Nature. So the point is if we can find empirical data in Nature about them. The same is valid for also jinn. Jinn cannot be examined scientifically since they are supernatural. Can we have a jinn or any sign about it to investigate empirically? I do not think (PST 2).

Neither miracles nor jinn can be investigated scientifically. Firstly miracles are exceptional events. They did not obey the rules of mechanic Nature. Science is interested in laws but not in exceptions. Jinn is out of the physical universe and hence supernatural. They cannot be examined (PST 18). 
While the responses of the Group 3 participants differed in relation to either accepting or rejecting the possibility of investigating miracles and jinn scientifically, they provided similar reasons. Their opinions were consistent with their previous claims regarding a mechanical Nature as the basic assumption of science, maintaining the scope of lawful Nature and requirement of yielding empirical data.

\section{Discussion}

Participants of the study expressed their belief in a created Nature which is lawful and understandable. They supported the assumption of being lawful with the premise of empirical investigation of natural causes in accordance with the proposed pillars of modern science (Hocaoglu 1996; Aikenhead 2006; Matthews 2009a). On the other hand, they also asserted that Nature is open to supernatural intervention in the form of miracles. They labeled miracles as exceptional cases that do not rule out the lawful operation of Nature. As has been reported previously (Kearney 1984; Cobern 1994; Allen \& Crawley 1998; Tsai, 2001; Sutherland \& Dennick 2002; Liu \& Lederman 2007; Çakır 2008; Mansour 2011), participants' individual ontologies determined their conceptions of science and the presuppositions they assumed for scientists in order to conduct science. The great majority of theist participants (20 out of 23) asserted that scientists can behave as theists while conducting science although an important portion of them (10 out of 23) were also open to naturalism. However, a small portion of theist participants ( 3 out of 23) assumed science as a distinct culture and presupposed just naturalism for scientists apart from their individual ontologies.

All of the participants, as theists, had declared their belief in Allah, the verses of Holy Qur'an, miracles and jinn. Apart from those proposing just naturalism for science, theist participants predominantly asserted that Allah would be considered as a meta-concept in scientific enterprise that motivates scientists in their work. Their approach was an attempt to reconcile their individual ontologies with the practice of science. They claimed Islamic Science (Loo 2001; Mansour 2011) comprising some religious motives in the research of Nature, but adopted the methodology of Western Science, namely methodological naturalism (Irzik \& Nola 2009). Theist participants could be viewed as having adapted to the culture of modern science, since as Matthews (2009b) argued, methodological naturalism does not disregard religious cases (e.g. miracles or Divine interventions) but means that such processes cannot be appealed to whilst seeking scientific explanations. Their tendency was to stand in the milieu of modern science without losing the meaning they individually held about it. Such a position evoked the criticism of Cobern (2000a) about the radical empiricist worldview which is often associated with modern science for eroding society's meaningful sense of life.

The participants asserted the physical universe as the boundary for science and evaluated the possibility of the scientific investigation of miracles and jinn within that boundary. They all declared their belief in miracles/jinn and answered the issue of whether miracles/jinn can be the subject of science either positively or negatively, but maintaining their commitment to the need to be able to obtain empirical data through methodological naturalist approach (Eastwell 2011; Fishman 2009). Their stance was in accordance with the widely accepted scientific attitude and premises of modern science (Gauch 2006; Cobern \& Loving 2001). The participants' positions about the role of beliefs in scientists' work were also partially based on the methodological naturalist approach and the boundary they established for science. Some of the participants (7 out of 23) indicated a belief-laden scientific practice. On the other hand, the remaining participants (16 out of 23) viewed science as being blind to any element of faith. The participants who proposed belief-laden scientific practice focused on religious beliefs and indicated that scientists should diverge in the interpretation of data because of their religious beliefs (Lederman 2004; Lederman, Abd-El-Khalick \& Akerson 2000; Lederman, Abd-El-Khalick, Bell \& Schwartz 2002). They asserted that theist scientists have answers to existentialist questions in advance provided to them by Islam. On the other hand, the great majority of participants (16 out of 23) proposed a belief-free approach to science. They indicated that in order to understand Nature, scientists conduct research in an objective and empirical manner; therefore they should inevitably conclude the same physical laws. They totally ignored the role of paradigms, beliefs and individual philosophies in the construction of knowledge and proposed a beliefblind mechanical process (Cobern 2000a; Akerson, Abd-El-Khalick \& Lederman 2000).

The participants' opinions about Islamic propositions comprising natural entities/processes, namely the physical universe, were also coherent with their assumptions of the role of beliefs in science and the ontological presuppositions they asserted for scientists. The majority of participants had purported that Holy Qur'an would be considered as a source of knowledge claims by scientists (Mansour 2011). For them science is open to all kind of knowledge sources and hence to religious texts. They labeled any bias in this context as being restrictive but that did not mean they were unconditional. They stuck to the boundary they set for science as being open to empirical testing and being in the scope of Nature as discussed by Fishman (2009) and Eastwell (2011). 


\section{Conclusion}

Before reaching a conclusion, it must be explicitly mentioned that results of this research cannot be extended directly to wider populations because of the nature of qualitative approach preferred. So, the results and conclusion can be thought as valid for just the groups having similar qualities with the study group.

The results of the study implied that although theist participants believed in a created Nature that is open to the intervention of Allah, they did not deny the principles of causality and lawfulness in the operation of physical processes in general. They consider miracles as exceptional phenomena. Therefore, their faith in miracles did not corrupt their perceptions regarding those basic assumptions of modern science. A participant who believes in miracles does not refute, therefore, that Nature behaves orderly according to the physical laws. On the other hand, participants diverged in their conceptions of the ontological basis of modern science. While majority of them asserted that scientists can perform research with either a theist or naturalist view, some participants proposed that they only held onto a naturalist view which may contradict their personal ontologies. Such a position indicated that not all of the theist participants feel obliged to reconcile their individual ontologies with the modern science. They perceived science as a discrete intellectual activity, appreciated it and did not consider the exclusion of theism from science as a cause of crisis.

Although the participants' declared that they strongly believe in miracles and jinn, they depended on the possibility of having either direct or indirect empirical data in scientific investigation of those supernatural entities. They did not tend to construct their faith on the findings of science and hence were not inclined to push the limits of science (e.g. distorting the methodology of science towards pseudo-scientific contexts) in order to support their belief in supernatural. In fact, they were not conditioned to confirm their theistic views with scientific research. The participants' respect for the methodology of science was also considered in the case of knowledge claims that originated in Islam. They consistently asserted that those claims should be noticed if it is possible to obtain related empirical data and did not absolutely separate knowledge claims as religious or scientific. The participants instead focused on whether these claims have potential of being empirically testable in order to be in the scope of the modern science.

Overall, participants engaged in rich conversations regarding causality, lawfulness and empirical processes while arguing ontological basis of science and supernatural. An absolute conflict or integration perspective for science and theism was not explicitly determined in their statements. While they maintained a strong theistic faith that also partially shaped their conception of science (e.g. motivation role), they were simultaneously ready to respect the methodology of science in the case of any scientific discourse (methodological naturalism).

\section{References}

Aikenhead, G. S. (2006). Science education for everyday life: Evidence-based practice. New York: Teachers College Press.

Akerson, V. L., Abd-El-Khalick, F., \& Lederman, N. G. (2000). Influence of reflective explicit activity-based approach on elementary teachers' conceptions of nature of science. Journal of Research in Science Teaching, 37, 295-317.

Allen, N. J., \& Crawley, F. E. (1998). Voices from the bridge: Worldview conflicts of Kickapoo students of science. Journal of Research in Science Teaching, 35(2), 111-132.

Beeth, M., \& Kwak, Y. (2001, March). Impacts of ontology and epistemology on conceptions of science teaching and learning. Paper Presented at the Annual Meeting of the National Association for Research in Science Teaching, St. Louis, MO, USA.

Bogden, R. C., \& Biklen, S. K. (2007). Qualitative research for education: An introduction to theories and methods. Boston: Allyn and Bacon.

Cobern, W. W. (1994, March). Worldview theory and conceptual change in science education. Paper Presented at the Annual Meeting of the National Association for Research in Science Teaching, Anaheim, CA, USA.

Cobern, W. W. (2000a). The nature of science and the role of knowledge and belief. Science \& Education, 9(3), 219-246.

Cobern, W. W. (2000b). Everyday thoughts about nature: A worldview investigation of important concepts students use to make sense of nature with specific attention to science. Dordrecht: Kluwer Academic Publishers.

Cobern, W. W., \& Loving, C. C. (2001). Defining "science" in a multicultural world: Implications for science education. Science Education, 85, 50-67. 
Colburn, A., \& Henriques, L. (2006). Clergy views on evolution, creationism, science, and religion. Journal of Research in Science Teaching, 43(4), 419-442.

Creswell, J. W. (2012). Educational research: Planning, conducting and evaluating quantitative and qualitative research. Boston, MA: Pearson Education Inc.

Çakır, M. (2008). Constructivist approaches to learning in science and their implications for science pedagogy: A literature review. International Journal of Environmental \& Science Education, 3(4), 193-206.

Çakır, M. (2011). Epistemological dialogue of validity: Building validity in educational and social research. Education, 132(3), 664-675.

Dilworth, C. (2006). The metaphysics of science: An account of modern science in terms of principles, laws and theories. Dordrecht: Springer.

Eastwell, P. (2011). Supernatural explanations: Science or not? Science Education Review, 10(1), 17-26.

Fishman, Y. I. (2009). Can science test supernatural worldviews? Science \& Education, 18, 813-837.

Gauch, H. G. (2006). Science, worldviews, and education. Science \& Education, 18(6-7), 667-695.

Gay, L.R., Mills, G.E., \& Airasian, R. (2006). Educational research: Competencies for analysis and applications. Upper Saddle River, NJ: Pearson.

Guba, E., \& Lincoln, Y. (1994). Competing paradigms in qualitative research. In N. Denzin, \& Y. Lincoln (Eds.), Handbook of qualitative research (pp. 105-117). Thousand Oaks, CA: Sage Publications.

Haack, S. (2003). Defending science within reason: Between scientism and cynicism. Amherst, NY: Prometheus.

Hocaoğlu, D. (1996). Bilim ve inanç/imân üzerine felsefî bir irdeleme (A philosophical examination on science and belief/faith). Köprü, 53, 58-89.

Irzik, G., \& Nola, R. (2009). Worldviews and their relation to science. Science \& Education, 18(6-7), 729-745.

Kearney, M. (1984). Worldview. Navato, CA: Chandler \& Sharp Publishers, Inc.

King, N., \& Horrocks, C. (2010). Interviews in qualitative research. London: Sage.

Kvale, S., \& Brinkmann, S. (2009). Interviews. Thousand Oaks, CA: Sage.

Lederman, N. G. (2004). Syntax of nature of science within inquiry and science instruction. In L. B. Flick, \& N. G. Lederman (Eds.), Scientific inquiry and nature of science (pp. 301-317). Dordrecht: Kluwer Academic Publishers.

Lederman, N. G., Abd-El-Khalick, F., \& Akerson, V. (2000). Influence of a reflective explicit activity-based approach on elementary teachers' conceptions of nature of science. Journal of Research in Science Teaching, 37, 295-317.

Lederman, N. G., Abd-El-Khalick, F., Bell, R. L., \& Schwartz, R. (2002). Views of nature of science questionnaire: Toward valid and meaningful assessment of learners' conceptions of nature of science. Journal of Research in Science Teaching, 39(6), 497-521.

Liu, S.-Y., \& Lederman, N., G. (2007). Exploring prospective teachers' worldviews and conceptions of nature of science. International Journal of Science Education, 29(10), 1281-1307.

Loo, S. P. (2001). Islam, science and science education: Conflict or concord? Studies in Science Education, 36(1), 45-77.

Mansour, N. (2011). Science teachers' views of science and religion vs. the Islamic perspective: Conflicting or compatible? Science Education, 95(2), 281-309.

Matthews, M. R. (2009a). Teaching the philosophical and worldview components of science. Science \& Education, 18, 697-728.

Matthews, M. R. (2009b). Science, worldviews and education: An introduction. Science \& Education, 18, 641666.

McComas, W. F., Clough, M. P., \& Almazroa, H. (2000). The role and character of the nature of science in science education. In W. F. McComas (Ed.), The nature of science in science education: Rationales and strategies (pp. 3-39). Dordrecht: Kluwer.

Smart, J. J. C. \& Haldane, J. J. (1996). Atheism and Theism. Wiley-Blackwell.

Snively, G. J., \& Williams, L. B. (2008). "Coming to know": Weaving aboriginal and western science knowledge, language, and literacy into the science classroom. L1 - Educational Studies in Language and Literature, 8(1), 109-133.

Sutherland, D., \& Dennick, R. (2002). Exploring culture, language and perception of the nature of science. International Journal of Science Education, 24(1), 1-25.

Taber, K. S., Billingsley, B., Riga, F., \& Newdick, H. (2011), Secondary students' responses to perceptions of the relationship between science and religion: Stances identified from an interview study. Science Education, 95(6), 1000-1025.

Tsai, C.-C. (2001). Ideas about earthquakes after experiencing a natural disaster in Taiwan: An analysis of students' worldviews. International Journal of Science Education, 23, 1007-1016.

Turgut, H. (2011, July). Rethinking the nature of science instruction: Conceptions about metaphysical core of modern science in the context of preservice teachers' worldviews. Paper Presented at the $11^{\text {th }}$ 
International IHPST \& $6^{\text {th }}$ Greek History, Philosophy \& Science Teaching Joint Conference, Thessaloniki, Greece.

Uschold, M. (1996, December). Building ontologies: Towards a unified methodology. Paper Presented at the Annual Conference of the British Computer Society Specialist Group on Expert Systems, Cambridge, United Kingdom.

Yore, L. D. (2008). Science literacy for all students: Language, culture, and knowledge about nature and naturally occurring events. L1-Educational Studies in Language and Literature, 8(1), 5-21.

Yore, L. D., \& Knopp, T. (2001, January). An elementary preservice teacher's search for solutions about the evolution-divine creation question: The story of Tracy. Paper Presented at the Annual International Conference of the Association for the Education of Teachers in Science, Costa Mesa, CA, USA.

\section{Author Information}

\section{Halil Turgut}

Sinop University

Education Faculty, Science Education Department

Korucuk Köyü No:35 57000 - Sinop / Turkey

Contact email: halil.turgut@yahoo.com

\section{Appendix}

\section{Open-Ended Questions}

1) Identify your individual perspective about "Nature" please. For instance;

a) Nature is a mechanic system operating itself according to constant laws. We do not need any "Supreme Being" in order to explain this system. The laws which are determinant in the operation of "Nature" did not change over time and also will not in the future; mystical and miraculous events are not possible.

b) Nature is created by "Allah" as a system operating by determined principles and dedicated for the benefit of human being. Allah can manipulate the principles (laws) of the system; particular effects should not cause particular results all the time (miracles). We can infer about the existence and absolute power of Allah by examining the created "Nature".

c) Nature is created by a "Supreme Being" as a system operating by determined principles and dedicated for the benefit of human being. After the creation, "Supreme Being" did not intervene "Nature" and let the system operating itself. Human being can infer about the existence and absolute power of this "Supreme Being" by examining the created "Nature".

d) Please mention if you have any other views...

2) Does "Modern Science" presuppose any particular perspective of "Nature"? If yes, identify that perspective and compare it with your individual perspective of "Nature".

3) Do you think a scientist should cite "Allah" in any part of modern science?

4) Can we talk about the boundaries of "Modern Science"? Can there be any subject areas that "Modern Science" would not be dealt with? For instance do you think the propositions about "jinn" and "miracle" would be examined scientifically?

5) Can some propositions presented in religious texts and Holy Qur'an with regard to physical entities or nature be subject of modern science? Can scientists investigate them scientifically?

6) Will there be any differences between the scientific works of theist (Muslim) and atheist scientists? If yes, please identify what type of differences would be at which stages of their work? 